of the Pyrenees on the frontier between France and Spain. A brief account of this station is given in the Electrician of March 8. The President of the French Republic (as successor to the Kings of France) and the Bishop of Urgel in Spain share as co-princes the over-lordship of Andorra, a condition which has lasted since the early part of the ninth century. Radio Andorra is situated on a rocky hill at an altitude of 2,920 ft. above sea-level, but its aerial is placed at an altitude $2,460 \mathrm{ft}$. higher and is suspended across a lake; the supports, $410 \mathrm{ft}$. high, are $820 \mathrm{ft}$. apart. The feeder cable between the station and the aerial is $2,788 \mathrm{ft}$. long and is believed. to be the only case in which a distance of this order separates a transmitter and its antenna, with the exception of the Eiffel Tower, where ultra-short waves had to be considered. At Andorra transmitters for medium and short waves are installed. The energy required for the station is 350 kilowatts and is obtained from the Forces Hydro-électriques de l'Andorra, a water-power undertaking, which sells the bulk of its production outside the borders of this small State.

\section{Illness in Meat Packing Industry}

IN a recent paper (Public Health Rep., 54, 2196 ; 1939) Hugh P. Brinton, assistant statistician, Harry E. Seiffert, assistant public health engineer, and Elizabeth S. Frasier, junior statistician, United States Public Health Service, present an analysis of cases of sickness and non-industrial injuries lasting eight calendar days or longer among workers in the slaughter and meat-packing industry. The annual number of cases per 1,000 was $95 \cdot 0$ for white males, $144 \cdot 2$ for white females, and $137 \cdot 9$ for negro males, while the average number of days of disability per person was $3 \cdot 16,4 \cdot 85$ and $4 \cdot 01$ respectively. Those who showed the highest figures in the form of an excess of respiratory diseases were cold-meat workers among white males, scalers, wrappers and packers among white females, and by-product workers among negro males.

Very excessive rates for rheumatic diseases were found in certain occupations, especially those of warm- and cold-meat workers, sausage and casing workers, and curing workers. As regards environmental conditions, white males exposed to high humidity or wet had the highest rates, with non-respiratory and non-digestive diseases most in excess. Among white and negro males the highest incidence was found among those working in hides and wool, or glue and entrails, among whom digestive diseases were much commoner than the average. White males and white females showed sickness-rates in decreasing order of magnitude as follows: semiskilled workers in manufacturing, labourers, and clinical workers.

\section{New Seismographic Equipment in the United States}

A NEW seismograph station has been established at Lincoln, Nebraska, and new equipment has been installed at Chicago, Salt Lake City, and Bozeman, Montana, all co-operating stations of the United
States Coast and Geodetic Survey, according to J. H. Nelson and H. E. McComb. The new seismograph station is on the campus of the Nebraska Wesleyan University in Lincoln, Nebraska, and is situated on a layer of loess and glacial clay $150-175 \mathrm{ft}$. thick, under which is several hundred feet of Cretaceous sandstone. The position is latitude $40^{\circ} 49 \cdot 1^{\prime} \mathrm{N}$., longitude $96^{\circ} 42 \cdot 2^{\prime}$ W., altitude $358 \pm 5$ metres.

The seismograph operates as an east-west component and is a small experimental McComb-Romberg tilt-compensation seismometer having magnetic damping and a clock-driven completely enclosed recorder. Time control is furnished by a Seth Thomas pendulum clock compared daily with naval radio time signals from Arlington. Tilt compensating instruments have been installed at Chicago on account of the slow irregular tilt movements of the pier on which the seismographs rest. Salt Lake City (latitude $40^{\circ} 45 \cdot 9^{\prime} \mathrm{N}$., longitude $111^{\circ} 50 \cdot 9^{\prime} \mathrm{W}$., altitude $1433 \pm 5$ metres) had a two-component $100-\mathrm{kgm}$. Bosch-Omori seismograph and has recently installed a two-component small model McCombRomberg tilt-compensation seismograph. At Bozeman, oil damping has been replaced by magnetic damping and the recording equipment has been improved.

\section{Smoke Abatement}

The National Smoke Abatement Society has issued its quarterly, Smokeless Air, on a reduced scale but. with a supplement "Smoke Abatement in War Time". This is an effort to rebut the belief that reduction of smoke under present conditions is unimportant. The impression that smoke serves a useful purpose by screening towns against air attack is challenged. A smoke screen may assist a moving object such as a ship, but serves as a landmark fixing the position of a stationary group such as a town. It may provide a screen to hinder the recognition of a specific object, but equally it conceals the attacker from the defence. Concealment is a great help to the submarine, and recent experience shows its assistance to raiding aircraft. The pamphlet directs attention to the way in which colliery tips serve as landmarks, providing a "difficult problem" in smoke abatement. The difficulty, it may be indicated, is less technical than political and due to the fact that the disposal of pit refuse is left to the discretion of the individual colliery. Naturally the cheapest possible method is used, regardless of the effect on the surrounding people, land and of the ultimate cost to the community. The chemical composition of pit refuse is such that self-ignition can scarcely be prevented when it is dumped in enormous heaps. Too often collieries are surrounded by low-lying land reduced to valueless swamp by mining subsidence. Pit refuse would serve a useful purpose, if used to raise the level of such land, and under such conditions firing would not occur.

Smoke results from the liberation of the volatile matter of coal, a large part of which is liquid. Smoke abatement is a movement for collecting this liquid for useful purposes instead of dispersing it as a public 